\title{
Culture Shock: Online Learning in the Covid- 19 Pandemic Phase
}

\section{Dewi Sri Kuning}

Pendidikan Bahasa Inggris, Universitas Muhammadiyah Kotabumi, Lampung Utara dewisrikuning@gmail.com

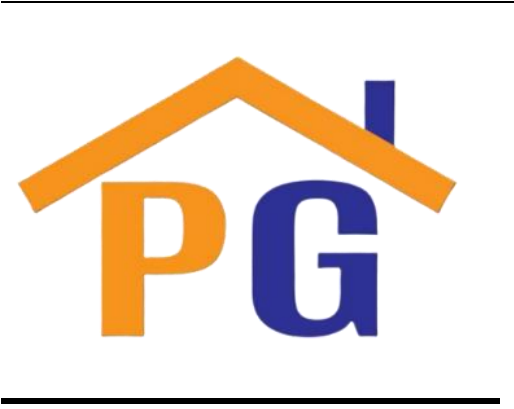

Riwayat Artikel

Diterima pada 28 April 2021

Direvisi pada 7 Juni 2021

Disetujui pada 11 Juni 2021

\begin{abstract}
Purpose: In this Covid-19 pandemic phase, all teaching and learning process is done by online learning. Online learning is one way the Indonesian government saves the education keep run well because all learning activities are done at home. However, the effect of this activity makes the students shocked. Not only the students but also the parents and the teacher feel the culture shock because of online learning: many advantages and disadvantages to online learning for students. This study gives some solutions for every challenge from online learning in the Covid-19 pandemic.

Research methodology: This is a review paper.

Results: This article elaborates on the psychological impact of online learning on students.

Limitations: This study only tells about the culture shock of online learning for students, teachers, and parents.

Contribution: This article can be helpful for school in adding information about the culture shock of online learning and how to solve it.

Keywords: Covid-19 pandemic, Culture shock, Online learning

How to cite: Kuning, D. S. (2021). Culture shock: Online Learning in the Covid-19 Pandemic Phase. Jurnal Humaniora dan Ilmu Pendidikan, 1(1), 55-62.
\end{abstract}

\section{Introduction}

There is a dangerous virus spread across the globe since the end of 2019. The virus's name is Coronavirus disease (Covid-19), which was first identified in Wuhan, China on December 2019 and spread quickly worldwide for a few weeks (Omrani, 2020). Many countries in the world did lockdown for all activities because the government wants to save society from this virus (Mishra et al., 2020). This decision disturbs all society's activities like economics, education, public places, and many more. Coronavirus disease becomes the biggest problem all over the world until now. In Indonesia, March 2020 is the beginning of lockdown activity for all sectors of life, including education. The circular letter from our Ministry of Education number 36962/MPK.A/HK/2020 said that all educational activities in school or university are done in online learning to prevent the Covid-19 pandemic.

Education is one of the important things in human life. Education is one way to prepare good human resources because education can create the next generation with good quality and compete with other countries in the world. The government of Indonesia has a primary learning program for 12 years Law number 20 about National Educational System 2003 for all society of Indonesia. However, because Covid-19 pandemic, many education institutions enclose the activity because of this virus. All students have a new activity in learning that is online learning, where the learning activity runs by the internet. It means that between the teacher and the students do not meet face to face, but they meet by internet by using platforms of learning, such as WhatsApp, Zoom Meeting, Google Meet, Ed Link, and many more. This new activity of learning hopes can make the learning process still run well, although by online learning. The Indonesian government carefully evaluates the pandemic to prevent the spread of Covid-19 infection (Brahma, 2020) (Djalante et al., 2020). Meanwhile, the World Health Organization (WHO) issued health protocols to prevent the outbreak and delay worldwide spread. 
However, information on the spread of infection quickly makes the public panicked, anxious, and fear resulting in a spate of panic buying on face masks, food and necessities, medicines and vitamins, herbs, and other herbal medicines.

Learning from home is implemented with the Distance Learning system. In the Law No. 20 of 2003 article 1 paragraph 15, it is explained that Learning from Home is educated. Students are separated from educators and learning using various learning resources through communication technology, information, and media. Learning from home is divided into two approaches in its implementation, namely distance learning in-network (online) and offline distance learning. In the implementation of Learning from Home, education units can choose an approach (online or offline or online) combination of both) in accordance with the characteristics and availability, facilities, and infrastructure readiness (Asmuni, 2020). One type of Learning from Home is online learning. System online learning is a learning system without face-to-face between teachers and students, but online using the internet network.

A new habit of learning in the education world has made culture shock for the students. The students have a new activity in learning that is by online learning uses handphone or laptop. This new habit is coming from the decision of the government to save all society from this virus. Online learning is one shape of social distancing between societies in preventing Corona disease. However, the implementation of online learning is not maximally because many weaknesses from the teacher adapt to the digital world (Covid-, 2020). The students who feel culture shock from online learning and the parents, teachers, and all people in the education field.

\section{Theoretical Review}

\subsection{Online Learning}

Internet is a source of learning to help the teacher explain the teaching material to enrich the student's knowledge. Besides that, the internet can help the teacher send the message of learning quickly and easily. Right now, the internet is very familiar with the students, especially in online learning in the Covid-19 pandemic. The internet can help the students look for the material of learning quickly and easily and up to date without any trouble. However, there are some skills which must be there for the students in using the internet in online learning (Us \& Kompri, 2008), they are:

1. Web: the facility to show text, picture, sound, animation, and other multimedia data by internet.

2. Email: a letter which can be sent by internet or provider.

3. Browsing: a technical term of internet which has a meaning to investigate the internet world.

4. Upload: the data transfer by digital communication tools from a smaller system.

Online learning encompasses a range of technologies such as new groups and texts, the worldwide web, chat, email, audio and video conferencing delivered over computer networks which are used for education needs (Medford, 2004). Online learning is used for the students to learn at their own place, based on their convenience. Especially in the Covid-19 pandemic, mostly all parts of education in the world uses online learning. Online learning is one solution to save learning for the students, although not face to face.

(Pozna \& Sk, n.d.) divided online learning into two parts. The first is a partially online course. It integrates existing resource materials that are available either in print or non-print form, such as textbooks, with some elements of online learning. The second is a fully online course. It is one that will have most of its learning and teaching activities carried out online. Since the Covid-19 pandemic holds to all over the world, mostly the education style uses fully online learning to distort society.

In conducting online learning, many advantages and disadvantages affect the students. According to (Medford, 2004), some advantages of online learning for the students are:

1. Accessibility: the students can access everywhere and anywhere. It means that the students can choose the appropriate place for them to learn because they were not limited by time or space grouped into a comfortable, educational environment theme. 
2. Personalised learning: the students can determine by themselves about the learning style, aim, content, individual skills, and current knowledge. By E-learning, the individual can plan their own learning. It has the potential to develop confidence and self-esteem, motivate, reduce the barriers of the students in learning, improve the learning experience, personalize the learning experience. Also, they can develop their ability in ICT skills.

3. Develops Cognitive Abilities: the students of E-learning have higher achievement levels than their counterparts. They can learn everything only with the click of one button because many providers of learning can help the students easier in studying by online learning.

4. Cost-Effectiveness: online learning can reduce learning costs because the students do not need to buy book, travell, and college context. Since it can be carried out at any geographic location and there are no travel expenses, this type of learning is less costly than learning at a traditional institute.

5. Promotes Research: the students can produce something of extremely high quality. Publishing the students' work can help form a classroom legacy and archive of a successful product.

6. Basic Computer Skills: by online learning, the students will always be familiar with computer because they mostly use it to do some assignments. So, their ability in Information Communication Technology (ICT) will improve.

7. Equal Opportunity to All: all students are equal, no matter if they are a disability or come from a different race, religion, caste, sex, creed, and others. Online learning gives the same opportunity for students to study together and become smart, although in the Covid-19 pandemic.

8. Self-Pacing: every student has a different ability to accept the materials from the teacher. By online learning, the students can choose their own pace without the time restriction. The Learner is free to complete the course work according to his own will and he can take as much time as he requires without being termed as slow by his peers.

9. Globalization: online learning means technology grows very fast because the students study by using the internet and other tools as the way to follow the development of technology. Besides that, the teacher also studies using the platform of learning, searching the new information, sharing ideas and knowledge, interacting with experts, and using the online database.

Besides the advantages of online learning, it also consists of the disadvantages (Medford, 2004), they are:

1. Poor Communication: since the students learn by using online learning, they do not have the opportunity to face their teacher face-to-face. It makes misunderstanding or less perception about the material given, making them have poor communication with the teacher.

2. Feeling Isolated: the students must join the online learning without any friends beside them as usual. This condition makes the students stress because they can not interact directly with friends or teachers. Studies show that feeling of isolation was a huge stress factor that prompted students to drop out.

3. Lack of Motivation: online learning makes the students lack motivation because they easily get distracted by other things. Sometimes they get great spirit, support from friends and the teacher at school. However, this condition makes them less of spirit to learn.

4. Lack of Fund: points out that technology's downsides include cost, hardware issues, internet problems, production of course materials and worry about the availability of funds.

5. Lack of Quality: the result of the students by online learning sometimes has low quality. Nononline faculty has problems concerning the credibility of online courses. Besides that, the instructors give less preparation in giving the materials. It makes low quality on the result of learning.

So, online learning has advantages and disadvantages. The most important is how the teachinglearning process must be run well, although in the condition of Covid-19 pandemic, in order to keep the teaching-learning process safe. 


\subsection{Culture Shock}

(Culture, 2021) Culture shock means the situation and one's feelings in the face of different social problems. Culture shock disturbs individuals who suddenly move to a new culture. Culture shock is the series of emotional reactions to unexpected cultural differences and which cause feelings of helplessness, irritability, and fear of being deceived, hurt, or ignored. Culture shock is a variety of experiences that result from various stress when contact with other cultures. Based on some opinions above, culture shock is confusing or disorienting, which occurs when someone enters a new place with a different culture. The culture shock of someone can be seen from this figure:

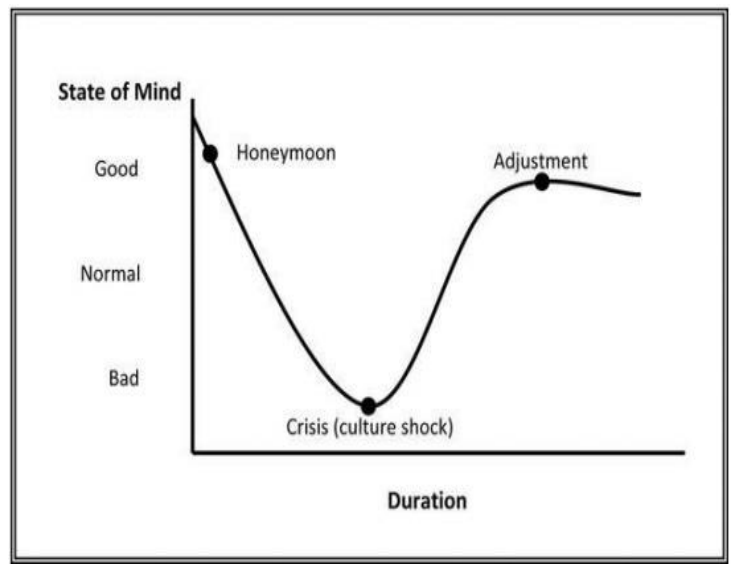

Figure 1. Phase of Culture Shock

Source: (Chase, 2002) in (Khoirunnisa \& Soemantri, 2019)

There are three phases of culture shock that are drawn from the figure. The first is the Honeymoon phase. It is about the happiness, full hope, and euphoria of the people before entering the new world. The second is Crisis/culture shock. It is about a crisis that happens to someone because new habits and new problems arise. The third is adjustment. This phase placed someone in the new culture. Based on the figure, the students face culture shock because they have a new habit in education: online learning. The effect of culture shock, which happens to someone, can vary, starting from easy problems to complex problems. Besides that, it may be quickly or slowly (Simanjuntak \& Fitriana, 2020). Culture shock has six characteristics, as stated by (Mitasari \& Istikomayanti, 2019). They are: first, the tension in psychological adjustment; second, the feeling as if individuals have lost a friend, status, social role, and personal position; third, the rejection of new culture; fourth, confusion in roles, values, feelings, and self-identity, fifth, shock and anxiety there are different cultures, and the last inability to adapt with the new environment.

According to (Putri et al., 2018), culture shock in online learning can happen to students, teachers, and parents in online learning. The students have limited communication and outreach among students, higher challenges for students with special educational needs, and longer screening times. Besides that, teachers must prepare well for online learning, including some restrictions in the choice of teaching methods, less curriculum material coverage, the lack of technical skills that hinder the potential for online learning, longer screen time as a result of creating e-content and providing feedback on student work, more intense and time-consuming communication with parents, and they feel higher in internet bills. So, it can be said that online learning brings culture shock for all component of education, the students, parents and the teachers.

The parents' part in education for the children is as providers, teachers, and problem solvers (Kurniati et al., 2020). (Purwanto et al., 2020) also gives some duties of the parents in accompany his children in studying at home, like giving motivation, providing the learning tools, buying other types of 
equipment of learning, teaching the children well, signing the homework book, checking the children homework, asking the children result at school, and asking the children difficulties in learning.

(Medford, 2004) give the psychological impact of online learning for the students, they are:

1. Frustration and online learning: frustration is the most pervasive emotion associated with online learning. Many students feel frustrated because of online learning and it is correlated with the use of technology. Many times learners cannot log on or the links/the page do not work. Besides that, it also because of the lack of explicit instruction from the teacher. It is also related to the design, structure and relevance of the website content and computer anxiety with the learning processes, especially discussion groups.

2. Fear, anxiety, apprehension and online learning: online learning sometimes is done by using the computer. The students feel anxious about operating a computer if they do not have enough skills to operate it. Besides, more minuscule other electronic tools like a handphone also become the problems of the students in doing online learning.

3. Stress, Depression and Online Learning: online learning can increase the depression of the students. There have been reports of internet-related deaths, such as cardiac arrests resulting from sleep deprivation and lack of personal maintenance or suicide due to net-related stress. Besides that, online learning is associated with behavior and impulse problems like over-involvement in online relationships and compulsive web surfing or database searches (information overload).

(Chafsoh, 2020) states that culture shock experienced by new students during online learning caused by worry about his new world of education. Disconnection of face-to-face social interaction, a face that has turned entirely online, makes students estimate and own expectations about what occurs in the social environment and circumstances to themselves. The expectations of new students are raised to become too much to measure the situation themseves to the real state yet occur. Predicting something and excessive overthinking trigger psychological effect such as stress and other disturbances in the pattern of life.

The culture shock of the students is because they have many assignments of academic, interpersonal problems, teaching-learning process, social relationship, and group effect (Rajasekar \& Renand, 2013). From this statement, it can be seen that too many assignments are given to students as the effect of online learning. It is one reason why online learning can make the students shocked. Besides that, many students still have their behavior in finishing the assignment, accustomed to relax, and have many free days when pandemic. This new habit makes the students feel shocked because they are not ready yet to do it all. Covid-19 pandemic, lockdown, and online learning make the students shocked because new things or new habits come suddenly without any preparation. Moreover, online learning can make the students depressed. So, the government must give the best solution to reduce those problems to save education in Indonesia.

\subsection{Solution of Culture Shock in Online Learning}

Online learning is done because the government wants to save people, especially children, to get an education. For the first time, many societies fell the culture shock because online learning was a new activity for them during a lockdown. Many challenges must be repaired in online learning to reduce the culture shock of the students. (Goel, 2020) gives some challenges and the solution by online learning.

The first, online learning is a lack of awareness. Online learning is not effective as classroom training and the students would miss face-to-face interaction. The solution to this challenge is to promote online learning by publishing eBooks, blogs, or other social media about online learning and developing effective communication to make the students know the function and usage of online learning.

The second, in online learning students, lack motivation. It is because the teacher only explains the materials for a while to the students, and after that, they let the students do the exercises by themselves without accompanying the students. So, the students feel unmotivated. The solution to this challenge is to stimulate the learners' curiosity and set clear objectives. 
The third, in many experiences from online learning, the content is unstructured and difficult to comprehend. It is because the teachers do not give the appropriate methods in delivering the materials well, although by online learning. So, the solution to this challenge is by involving the Subject Matter Experts (SME). SME is proficient in various subjects and guides the instructional designers on the content received.

The fourth, the teachers must evaluate about the materials and the transferring of knowledge to the students are effective or not. So, the solution to this challenge is by incorporating effective assessments in the form of quizzes and puzzles.

The fifth, the psychology problem because of online learning is worried. It is crucial to constantly explore the implication of the pandemic for the students' mental health to minimize the effect. The teacher can always do screening for the students periodically to know the students who have the psychological problems.

Besides that, (Asmuni, 2020) also gives some solution in facing culture shock in online learning, they are: 1) teachers should prepare learning materials as attractive as possible, such as presenting material in powerpoint slides accompanied by videos learning so that the material is more lively felt by students; 2) in terms of limitations mastery of technology information, teachers can use technology that is simpler to operate, like the WhatsApp application. However, little by little, teachers must improve the competence of technology information, among others, by attending related workshops, asking other teachers who have more capabilities in the technology information field and feel quite easy as the author's experience, many follow tutorials on youtube that presents a lot of introduction to learning applications and the steps for their use, and how to produce learning videos; 3 ). students who "do not care" participating in online learning can be overcome by proactively contacting (via telephone/video call) students and their parents personally if not for home visits. 4), the subject teacher with the counseling teacher tried to find out what the problem was by contacting his parents. When the problem is that the child is lazy, then the BK teacher will ask his parents to be able to accompany the implementation of their child's Learning from Home.

Furthermore, for students who do not have devices or take turns, use them with parents, or do not have internet network access, participants can do assignments manually and, most importantly, keep learning and staying at home. The solution to the problem of parental factors is to communicate (via handphone/WhatsApp) with parents to take the time to come back soon home from work so that their children's mobile phones/gadgets are immediately used for study online; provide leeway for doing assignments so that students who can take turns using mobile phones/gadgets with their parents; ask guardian for help class to inform students' learning progress via WhatsApp group WhatsApp parent association so that parents are expected to be able to motivate and assist their children who pay less attention to the duties of the teacher; subject teacher asks active student assistance to inform unfinished bills by participants who are less concerned; subject teachers call directly the number student's cellphone to ask the reasons for not doing the assigned task given; ask for help from counseling teachers to motivate students in learning.

The explanation above illustrates that online learning can work according to the conditions experienced with various problems that arise, both simple and complex. Every problem encountered can be solved by present a variety of solutions from teachers so that learning during the Covid-19 pandemic 19 continues. The important thing is that children continue to learn and continue to learn even though they are BDR. The implementation of Learning from Home does not pursue curriculum completeness but emphasizes literacy and numeracy competencies. In the application of online learning, teachers use various technological devices in the field of education and are able to choose various applications according to the needs and characteristics of subjects, students, and environmental situations faced so that it can help to deliver learning material (transfer of knowledge) to students. However, it is recognized that in practice, the teacher is more dominant in giving assignments, not explaining the material. 


\section{Conclusion}

Culture shock is the most significant thing experienced by students, parents, and the teacher in online learning. Usually, they face to face in learning at school with the teacher and meet many friends. Online learning is a new culture for them because they must have new habits in learning. Besides that, many problems happened because of online learning; moreover, students get many assignments from teachers in online learning. So, it makes them very shocked because not all materials given by teachers in online learning are easy to be understood. Students need motivation as well psychological support so they are able to study with enthusiasm. The role of the family environment immensely helps new students experience culture shock so that students feel valued and feel there are still many people who care for them. Fix inner pattern thinking is also a reason for new students to respond to everything in their lives. The students must be ready to accept change and be grateful for what happened to be one of the keys in life happy as a student.

Online learning happened because of the Covid-19 pandemic that hit the world at the beginning of 2020. The educational world must do lockdown and students should study via online learning. So, as the solution to this situation, the students, parents, teacher, and all the people grouped in the educational world must adapt to a new normal condition. It means that one year is the time to practice in receiving this condition because if the learning is conducted face to face, it is hazardous, especially the students as a future generation. Online learning is done because our government wants that learning process to continue in pandemic conditions. After all, education is vital for human life. People, especially students, must be accustomed to online learning because no people know when the Covid-19 pandemic will end. New normal is a solution for the culture shock of the students.

\section{Acknowledgement}

Big thanks to the Rector of University Muhammadiyah of Kotabumi which has given the writer the opportunity to write this article. Besides, big thanks to Jurnal Humaniora dan Ilmu Pendidikan (Jahidik), which has given the opportunity to the writer in publishing this article.

\section{References}

Asmuni, A. (2020). Problematika Pembelajaran Daring di Masa Pandemi Covid-19 dan Solusi Pemecahannya. Jurnal Paedagogy, 7(4), 281. https://doi.org/10.33394/jp.v7i4.2941.

Brahma, B. (2020). Oncologists and Covid-19 in Indonesia: What Can We Learn And Must Do?. Indonesian Journal of Cancer, 14(1), 1. https://doi.org/10.33371/ijoc.v14i1.728.

Chafsoh, A. M. (2020). Munculnya Culture Shock Pada Mahasiswa Baru Dalam Perkuliahan Daring Selama Pandemi Covid-19. Jurnal Sejarah Artikel, 2-3. https://files.osf.io/v1/resources/tmpn6/providers/osfstorage/5fee0854e9ccb90344aede36?direct $=\&$ mode $=$ render.

Chase, M. (2002). Communication Between Cultures (4th ed.). International Journal of Intercultural Relations, 26(3). https://doi.org/10.1016/s0147-1767(02)00007-x

Covid-, S. P. (2020). Gambaran psikologis mahasiswa dalam proses pembelajaran selama pandemi Covid-19, 8(3), 299-306.

Culture, S. (2021). Peran Pendidikan Multiculturalisme Dalam Mencegah Culture. 2(1), 42-49.

Djalante, R., Lassa, J., Setiamarga, D., Sudjatma, A., Indrawan, M., Haryanto, B., Mahfud, C., Sinapoy, M. S., Djalante, S., Rafliana, I., Gunawan, L. A., Surtiari, G. A. K., \& Warsilah, H. (2020). Review and Analysis Of Current Responses To Covid-19 In Indonesia: Period of January to March 2020. Progress in Disaster Science, 6, 100091. https://doi.org/10.1016/j.pdisas.2020.100091

Goel, N. (2020). No Title. 2020, 4. https://blog.commlabindia.com/elearning-design/challenges-andsolutions-of-elearning

Khoirunnisa, Y., \& Soemantri, N. P. (2019). Fenomena Gegar Budaya pada Warga Negara Perancis yang Bekerja di Jakarta. Jurnal Antropologi: Isu-Isu Sosial Budaya, 21(2), 254. https://doi.org/10.25077/jantro.v21.n2.p254-261.2019

Kurniati, E., Nur Alfaeni, D. K., \& Andriani, F. (2020). Analisis Peran Orang Tua dalam 
Mendampingi Anak di Masa Pandemi Covid-19. Jurnal Obsesi : Jurnal Pendidikan Anak Usia Dini, 5(1), 241. https://doi.org/10.31004/obsesi.v5i1.541

Indonesia, K. N. R. (2003). Undang-Undang Republik Indonesia Nomor 20 Tahun 2003. Tentang sistem pendidikan nasional.

Medford, A. R. L. (2004). Online Learning. Quality in Primary Care, 12(1), 87-89. https://doi.org/10.4324/9780429355097-7

Mishra, L., Gupta, T., \& Shree, A. (2020). Online Teaching-Learning In Higher Education During Lockdown Period of Covid-19 Pandemic. International Journal of Educational Research Open, 1(September), 100012. https://doi.org/10.1016/j.ijedro.2020.100012

Mitasari, Z., \& Istikomayanti, Y. (2019). Hubungan Antara Culture Shock Dengan Hasil Belajar Mahasiswa Tahun Pertama. Jurnal Psikologi Pendidikan Dan Konseling: Jurnal Kajian Psikologi Pendidikan Dan Bimbingan Konseling, 4(2), 105. https://doi.org/10.26858/jpkk.v4i2.4316

Omrani, A. (2020). Coronavirus Disease 2019: The Story So Far. Libyan Journal of Medical Sciences, 4(2), 52. https://doi.org/10.4103/ljms.ljms_33_20

Pengelola Web Kemdikbud. SE Mendikbud: Pembelajaran secara Daring dan Bekerja dari Rumah untuk Mencegah Penyebaran Covid-19. https://www.kemdikbud.go.id/main/blog/2020/03/semendikbud-pembelajaran-secara-daring-dan-bekerja-dari-rumah-untuk-mencegah-penyebarancovid19.

Pozna, E. O., \& Sk, P. M. (n.d.). The E-Learning Component. 14(3), 58-68.

Purwanto, A., Pramono, R., Asbari, M., Santoso, P. B., Wijayanti, L. M., Choi, C. H., \& Putri, R. S. (2020). Studi Eksploratif Dampak Pandemi Covid-19 Terhadap Proses Pembelajaran Online di Sekolah Dasar. EduPsyCouns: Journal of Education, Psychology and Counseling, 2(1), 1-12. https://ummaspul.e-journal.id/Edupsycouns/article/view/397

Putri, C. P., Mayangsari, M. D., \& Rusli, R. (2018). Pengaruh Stres Akademik Terhadap Academic Help Seeking. Jurnal Kognisia, 1(2), 28-37. https://ppjp.ulm.ac.id/journals/index.php/kog/article/view/1544

Rajasekar, J., \& Renand, F. (2013). Culture Shock in a Global World: Factors Affecting Culture Shock Experienced by Expatriates in Oman and Omani Expatriates Abroad. International Journal of Business and Management, 8(13). https://doi.org/10.5539/ijbm.v8n13p144

Simanjuntak, D., \& Fitriana, R. (2020). Culture Shock, Adaptation, and Self-Concept of Tourism Human Resources in Welcoming the New Normal Era. Society, 8(2), 403-418. https://doi.org/10.33019/society.v8i2.200

Us, K. A., \& Kompri. (2008). Kebijakan Pendidikan Islam di Indonesia (Dahulu, Kini dan Masa Depan). 479. 